\title{
Vegetation and climate effects on soil production, chemical weathering, and physical erosion rates
}

\author{
Mirjam Schaller ${ }^{1}$, Todd A. Ehlers ${ }^{1}$ \\ ${ }^{1}$ University of Tuebingen, Department of Geosciences, Schnarrenbergstrasse 94-96, 72076 Tuebingen, Germany \\ 5 Correspondence to: Mirjam Schaller (mirjam.schaller@uni-tuebingen.de)
}

\begin{abstract}
Weathering of bedrock to produce regolith is essential for sustaining life on Earth and global biogeochemical cycles. The rate of this process is influenced not only by tectonics, but also by climate and biota. Here we investigate these interactions with new observations of soil production, chemical weathering, and physical erosion rates from the large climate and vegetation

10 gradient of the Chilean Coastal Cordillera $\left(26^{\circ}\right.$ to $\left.38^{\circ} \mathrm{S}\right)$. These findings are compared to a global compilation of published data from similar settings. The four Chilean study areas span (from North to South): arid (Pan de Azúcar), semi-arid (Santa Gracia), mediterranean (La Campana) and temperate humid (Nahuelbuta) climate zones. We test the hypotheses that: 1) soil production as well as chemical weathering rates increase with increasing mean annual precipitation; 2) physical erosion rates stabilize as vegetation cover increases; and 3) the contribution of chemical weathering to total denudation is constant over the

15 climate gradient.

We find observed soil production rates range from $\sim 7$ to $290 \mathrm{t} /\left(\mathrm{km}^{2} \mathrm{yr}\right)$ and are lowest in the sparsely vegetated and arid North, increase southward toward the vegetated mediterranean climate, and then decrease further South in the temperate humid zone. This trend is discussed and compared with global data from similar catchments underlain by granitic lithologies. Calculated chemical weathering rates range from zero in the arid North to a high value of $211 \mathrm{t} /\left(\mathrm{km}^{2} \mathrm{yr}\right)$ in the mediterranean zone.

20 Chemical weathering rates are comparable in the semi-arid and temperate humid zones $\left(\sim 20 \mathrm{t} /\left(\mathrm{km}^{2} \mathrm{yr}\right)\right.$. Physical erosion rates are low in the arid zone $\left(\sim 11 \mathrm{t} /\left(\mathrm{km}^{2} \mathrm{yr}\right)\right)$ and increase towards the South $\left(\sim 40 \mathrm{t} /\left(\mathrm{km}^{2} \mathrm{yr}\right)\right)$. Combined total chemical weathering and physical erosion rates indicate that denudation rates are lowest in the arid North and highest in the Mediterranean climate zone. The contribution of chemical weathering to total denudation rates increases and then decreases with increasing mean annual precipitation from North to South. The observation that the calculated chemical weathering rates in the southernmost

25 location, with the highest mean annual precipitation and the highest chemical index of alteration, are not the highest of all four study areas is found to be consistent with the global data analysis.
\end{abstract}




\section{Introduction}

Regolith forms through the weathering of rock near the Earth's surface and contains a mobile soil ${ }^{1}$ that overlies an immobile saprolite (weathered bedrock) (e.g., Heimsath et al., 1997; Riebe and Granger, 2013). Soil erosion results in the continual supply of weathered bedrock towards the surface and replenishment of nutrients for biota. Soil production in a soil-mantled hillslope occurs through complex interactions between tectonics (which influences the slope of topography and therefore erosion), rock type, climate (specifically precipitation and temperature), and biota; with all these interactions active over extended (millennial and greater) timescales (e.g., Mishra et al., 2019; Starke et al., 2020). Disentangling these interactions

35 has proved challenging and has previously been approached in study areas with diverse geologic, climate, and vegetation histories through the determination of soil production rates (e.g., Dixon et al., 2009; Dixon and von Blanckenburg, 2012; Heimsath et al., 2012; Larsen et al., 2014). In this study, the term soil production rate (SPR) is used as a general term for the production rate of bedrock into saprolite or soil. Under steady-state conditions, SPRs are considered equal to surface denudation rates which include mass loss through erosion and chemical weathering in soil and saprolite (e.g., Dixon et al., 40 2009).

Previous work in granitic lithologies for the calculation of chemical weathering rates was based on immobile elements (e.g., $\mathrm{Zr}$ or Ti) measured in soil, saprolite, and bedrock (e.g., Riebe et al., 2001). Denudation rates based on cosmogenic nuclides can be measured in river sediments, soil, or saprolite (see Riebe and Granger, 2013). A data set covering a mean annual precipitation (MAP) range of 220 to $4200 \mathrm{~mm} / \mathrm{yr}$ and a mean annual temperature (MAT) range of 2 to $25^{\circ} \mathrm{C}$ shows that the

45 highest weathering rates are reported from areas with rapid denudation rates (Riebe et al., 2004a). Although, chemical weathering rates are highly coupled with denudation rates, the importance of climate on weathering rates has also been recognized. For example, the influence of climate on soil production and weathering rates has been documented in altitudinal transects (e.g., Riebe et al, 2004b; Dixon et al., 2009; Ferrier et al., 2012). An observed steep decrease in chemical weathering rates with increasing altitude was attributed to changes in snow depth and vegetative cover (Riebe et al., 2004b). Previous work by Dixon et al., (2009) in another transect observed a peak in chemical weathering rates that correlated with physical erosion rates in middle elevation positions, which they attributed to climate variations along the transect. In contrast to the previous studies, chemical weathering rates from two transects below tree line elevation were found insensitive to regolith temperature differences as well as moisture content (Ferrier et al., 2012). Ferrier et al (2012) concluded that there is no significant change in weathering rates observed due to the lack of biotic changes along the transects. In contrast, in the extreme climate and vegetation gradient of the Chilean Coastal Cordillera $\left(26^{\circ}-38^{\circ} \mathrm{S}\right)$, previous work documented that the total denudation rates first increase from North to South and then decrease further South despite increasing mean annual precipitation and vegetation cover (Oeser et al., 2018, Schaller et al., 2018). The contribution of chemical weathering to total

\footnotetext{
${ }^{1}$ The terms regolith, soil, and saprolite used in this study follow the notation of Riebe and Granger (2013). This notation is not consistent with the one used in soil sciences (IUSS Working Group WRB, 2015) where the terms soil/regolith, pedolith, and saprolith would be used, respectively.
} 
denudation was found to be almost zero in the arid North, $\sim 50 \%$ in the semi-arid and mediterranean settings, but seems to be reduced again in the temperate climate of the southernmost study area (e.g., Oeser et al., 2018). Taken together, the previous studies highlight (with some unresolved inconsistencies) that climate and vegetation both have an important effect on soil production, chemical weathering, and physical erosion rates.

In this study we test the hypotheses that: 1) soil production as well as chemical weathering rates increase with increasing mean annual precipitation; 2) physical erosion rates stabilize as vegetation cover increases; and 3) the contribution of chemical weathering to total denudation is constant over the climate gradient. To test these hypotheses, soil production, chemical weathering, and physical erosion rates were investigated for four study areas along $\sim 1,300 \mathrm{~km}$ of the climate and vegetation gradient of the slowly eroding Chilean Coastal Cordillera. SPRs were calculated based on cosmogenic nuclide concentrations in saprolite published in Schaller et al. (2018) and used for denudation rate calculations by Oeser et al. (2018). In addition, we present 11 new cosmogenic nuclide concentrations from the latitudinal transect in the Chilean Coastal Cordillera. The calculation of chemical weathering and physical erosion rates follow the approach, notation, and methods described in Dixon et al., (2009) and make use of the geochemical data reported by Oeser et al. (2018). The four study areas in the Chilean Coastal Cordillera (Fig. 1) were selected because they contain a similar granitic lithology and tectonic history that allows focusing our analysis on how the extreme climate and vegetation gradient influences soil production, chemical weathering, and physical erosion rates. In addition, we compare observations from the Chilean study areas to previously published, and globally distributed, hillslope samples from granitic hillslopes. In doing this, we evaluate the interplay of topography, climate, and vegetation effects on soil production, chemical weathering, and physical erosion rates from diverse settings with a similar lithology.

\section{Chilean Study areas}

The four study areas are located in the Chilean Coastal Cordillera ( $26^{\circ}$ to $38^{\circ} \mathrm{S}$, Fig. 1; Table S1) and span (from North to South) climate and biogeographic zones ranging from arid to humid. Each area contains primarily granitic lithologies

80 (mostly granodiorite, tonalite, quartz diorite) and to a lesser degree gabbro in the Santa Gracia area (Oeser et al., 2018). The Coastal Cordillera lies along the west coast of Chile, where the neighbouring plate boundary is similar along strike due to subduction of the Nazca Plate. The study areas were selected to keep differences in lithology and tectonic setting to a minimum, and to enhance the signal of variable climate and vegetation on denudation rates.

In the following, we present the primary characteristics of the Chilean study areas that contain pedons in both South- and

85 North-facing slopes. In all the study areas, no signs of glaciation are reported in previous literature or our own field observations. One caveat worth discussion is that the data sets considered in this study are sensitive to different time scales. For example, cosmogenic nuclide-derived denudation rates typically integrate over timescales of $\sim 10^{2}-10^{6}$ years, whereas vegetation and climate change can occur over similar, and much shorter timescales. The comparison of modern climate and vegetation metrics to cosmogenic derived denudation rates sensitive to these different timescales can introduce uncertainty 
into any interpretation. However, recent work has quantified climate and vegetation changes in the four study areas since the Last Glacial Maximum (LGM) and up to the Pliocene (e.g., Mutz et al., 2018; Werner et al., 2018). While LGM climate was wetter and cooler, the climate and vegetation gradients present today also exist in the past (Starke et al., 2020; Mutz et al., 2018; Mutz and Ehlers, 2019), thereby diminishing concerns that modern climate and vegetation gradients are a poor representation of past conditions that cosmogenic nuclide-derived denudation rates may be sensitive to. With this potential complication in mind, we proceed with presenting the present-day characteristics of each study area. Numbers reported in sections 2.1 to 2.4 are from previous work by Bernhard et al. (2018), Oeser et al. (2018), Schmid et al., (2018), and Schaller et al. (2018).

\subsection{Pan de Azúcar}

In the northernmost study area Pan de Azúcar (Fig. 1; Fig. S1) MAP and MAT are $8 \mathrm{~mm} / \mathrm{yr}$ and $21.1{ }^{\circ} \mathrm{C}$ (Karger et al., 2017). The very sparse higher desert vegetation covers $2 \%$ of the land surface. The Regosol containing pedogenic gypsum has soil thicknesses of 20 to $25 \mathrm{~cm}$. The regolith has a clay content of $13.8 \pm 3.9 \%$, a bulk density of $1.3 \pm 0.1 \mathrm{~g} / \mathrm{cm}^{3}$, and a $\mathrm{pH}$ of $8.1 \pm 0.1$. The average chemical index of alteration (CIA; after Nesbitt and Young, 1982) in bedrock is 55 whereas the CIA in regolith is as low as 31 due to atmospheric input. Cosmogenic nuclide-derived denudation rates from South- and North-facing mid-slope positions are $11.0 \pm 0.7$ and $8.2 \pm 0.5$ $\mathrm{t} /\left(\mathrm{km}^{2} \mathrm{yr}\right)$ and dominated by physical erosion whereas chemical weathering is insignificant.

\subsection{Santa Gracia}

In Santa Gracia (Fig. 1; Fig. S1), MAP and MAT are $97 \mathrm{~mm} / \mathrm{yr}$ and $17.7^{\circ} \mathrm{C}$, respectively (Karger et al., 2017). The soil horizons of the Cambisol are 30 to $55 \mathrm{~cm}$ thick. The clay content of the regolith is $11.1 \pm 4.9 \%$, the regolith density is $1.5 \pm 0.0$ $\mathrm{g} / \mathrm{cm}^{3}$, and the $\mathrm{pH}$ Is $6.3 \pm 0.3$. The average CIA in the bedrock is $\sim 43$ which is similar to other granitic lithologies (i.e., 45 to

110 55; Nesbitt and Young, 1982), but lower than all the other study areas (52 to 55). The CIA in regolith horizons ranges from 49 to 52 , indicating regolith weathering. The cosmogenic nuclide-derived denudation rates in the South- and North-facing mid-slope positions are $22.4 \pm 1.5$ and $15.9 \pm 0.9 \mathrm{t} /\left(\mathrm{km}^{2} \mathrm{yr}\right)$. Chemical weathering rates are comparable to physical erosion rates.

\subsection{La Campana}

115 A mediterranean dry forest grows in La Campana (Fig. 1; Fig. S1) where MAP and MAT are $307 \mathrm{~mm} / \mathrm{yr}$ and $14.1^{\circ} \mathrm{C}$, respectively (Karger et al., 2017). This forest covers $84 \%$ of the land surface. The Cambisol contains 35 to $60 \mathrm{~cm}$ thick soil horizons and a clay content of $10.5 \pm 1.6 \%$. The regolith density is $1.3 \pm 0.2 \mathrm{~g} / \mathrm{cm}^{3}$ whereas the $\mathrm{pH}$ is $5.4 \pm 0.3$. The average CIA of the bedrock is 52 whereas the CIA of regoliths ranges between 52 to 56 . Values of the cosmogenic nuclide-derived 
https://doi.org/10.5194/esurf-2021-22

Preprint. Discussion started: 1 April 2021

(c) Author(s) 2021. CC BY 4.0 License.

denudation rates are $53.7 \pm 3.4$ and $69.2 \pm 4.6 \mathrm{t} /\left(\mathrm{km}^{2} \mathrm{yr}\right)$ for the South- and North-facing mid-slope positions. Reported chemical weathering rates are comparable to physical erosion rates.

\subsection{Nahuelbuta}

In the southern most study area of Nahuelbuta (Fig. 1; Fig. S1), the MAP and MAT are 1,479 mm/yr and $6.1{ }^{\circ} \mathrm{C}$ (Karger et al., 2017), respectively. The area contains a temperate mixed broadleaved-coniferous forest. Vegetation cover is as high as $95 \%$. The regolith type is an Umbrisol with soil horizons as thick as 60 to $90 \mathrm{~cm}$ and a clay content of $26.2 \pm 2.6 \%$ in the regolith.

125 Regolith density and $\mathrm{pH}$ are $0.8 \pm 0.1 \mathrm{~g} / \mathrm{cm}^{3}$ and $4.3 \pm 0.2$, respectively. The average CIA of bedrock is 54 , whereas values of regoliths are as high as 75 , indicating substantial weathering. Cosmogenic nuclide-derived denudation rates are $47.5 \pm 3.0$ and $17.7 \pm 1.1 \mathrm{t} /\left(\mathrm{km}^{2} \mathrm{yr}\right)$ in the South- and North-facing mid-slope positions. Chemical weathering rates are lower than physical erosion rates.

\section{Material and methods}

130 Soil production, chemical weathering, and physical erosion rates were determined for top-, mid-, and toe-slope positions in the South-facing slopes, whereas only the mid-slope is investigated for the North-facing slopes. Material analysed for ${ }^{10} \mathrm{Be}$ concentrations to calculate SPRs are collected from the top of the saprolite made accessible by pedon excavation (e.g., www.earthshape.net; Bernhard et al., 2018; Oeser et al., 2018). Cosmogenic nuclide concentrations of saprolite from 8 midslope positions are from Schaller et al. (2018) whereas 11 new top- and toe-slope position samples are presented here.

135 Representative photographs of pedons in each study area are published in Oeser et al (2018; Figures 3 to 6). In our study, the depths sampled in each pit are shown in Supplementary Material table S2. Saprolite material was crushed and sieved into a 0.25-1.0 mm fraction. Further cleaning of sample material and extraction of Be followed the methods as described in Schaller et al. (2018). For previous and all but one new sample location, chemical weathering and physical erosion rates were calculated from the SPRs and major and trace element concentrations in soil, saprolite, and bedrock. Major and trace element

140 concentrations used for samples are from Oeser et al. (2018). To summarize, we combine 11 new with 8 previously published cosmogenic nuclide concentrations to present 19 newly calculated SPRs and 18 newly calculated chemical weathering and physical erosion rates.

\subsection{Soil production rates}

SPRs from Chilean soil-mantled hillslopes (Table S2) were calculated as follows: The in situ-produced ${ }^{10}$ Be concentration of 145 quartz contains information about the regolith or SPR (e.g., Heimsath et al., 1997). The nuclide concentration C (atoms/g(qtz)) of the uppermost saprolite sample at the sample location is a function of:

$$
\mathrm{C}=\sum_{1}^{3} \frac{\mathrm{P}_{\mathrm{n}}(\mathrm{h}, \theta)}{\left(\lambda+\frac{S P R}{\Lambda_{\mathrm{n}}}\right)}
$$


where $\mathrm{P}_{\mathrm{n}}$ is the nuclide production rate (atoms $/\left(\mathrm{g}_{(\mathrm{qtz})} \mathrm{yr}\right)$ ) at sample depth $\mathrm{h}(\mathrm{cm})$ corrected for shielding $\Theta$ (unitless) by nucleonic, stopped muonic, and fast muonic production, respectively. No shielding by topography (less than 1\%) and snow has been taken into account whereas shielding by vegetation of $2.3 \%$ and $7.3 \%$ have been used in La Campana and Nahuelbuta, respectively (Plug et al., 2007). The SPR is the soil production rate $\left(\mathrm{g} /\left(\mathrm{cm}^{2} \mathrm{yr}\right), \lambda\right.$ is the decay constant $(/ \mathrm{yr})$, and $\Lambda_{\mathrm{n}}$ the mean nucleonic, stopped muonic, and fast muonic attenuation length of 157,1500 , and $4320 \mathrm{~g} / \mathrm{cm}^{2}$, respectively (Braucher et al., 2011). The nucleonic, stopped muonic, and fast muonic production rates at sea level high latitude of 3.92, 0.012, and 0.039 atoms $/\left(\mathrm{g}_{(\mathrm{qtz})} \mathrm{yr}\right)$ (Borchers et al., 2016) were scaled to the sample location based on Marrero et al. (2016).

\subsection{Chemical weathering and physical erosion rates}

The calculation of chemical weathering and physical erosion rates for the Chilean study areas follows the equations in Dixon et al. (2009). The sum of all mass loss $D_{\text {total }}\left[t /\left(\mathrm{km}^{2} \mathrm{yr}\right)\right]$ is given by:

$$
\mathrm{D}_{\text {total }}=\mathrm{SPR}+\mathrm{W}_{\text {sap }}=\mathrm{E}_{\text {soil }}+\mathrm{W}_{\text {soil }}+\mathrm{W}_{\text {sap }}
$$

where SPR is the known soil production rate $\left[\mathrm{t} /\left(\mathrm{km}^{2} \mathrm{yr}\right)\right], \mathrm{W}_{\text {sap }}$ is the chemical weathering rate for saprolite $\left[\mathrm{t} /\left(\mathrm{km}^{2} \mathrm{yr}\right)\right], \mathrm{W}_{\text {soil }}$

160 the chemical weathering rate for soil $\left[\mathrm{t} /\left(\mathrm{km}^{2} \mathrm{yr}\right)\right]$, and $\mathrm{E}_{\text {soil }}$ is the physical erosion rate for soil $\left[\mathrm{t} /\left(\mathrm{km}^{2} \mathrm{yr}\right)\right]$. Following Riebe et al. (2004a) and Dixon et al. (2009), $\mathrm{W}_{\text {sap }}$ can be expressed with the help of immobile elements in saprolite and bedrock as:

$$
\mathrm{W}_{\text {sap }}=\operatorname{SPR}\left(\frac{\mathrm{Zr}_{\text {sap }}}{\mathrm{Zr}_{\text {rock }}}-1\right)
$$

where $\mathrm{Zr}_{\text {sap }}$ and $\mathrm{Zr}_{\text {rock }}$ are the concentration of $\mathrm{Zr}$ in saprolite and bedrock, respectively. In contrast, $\mathrm{W}_{\text {soil }}$ can be expressed by:

$$
\mathrm{W}_{\text {soil }}=\mathrm{SP}_{\text {soil }}\left(1-\frac{\mathrm{Zr}_{\text {sap }}}{\mathrm{Zr}_{\text {soil }}}\right)
$$

165 where $\mathrm{Zr}_{\text {soil }}$ is the concentration of $\mathrm{Zr}$ in soil. $\mathrm{Zr}_{\text {soil }}$ and $\mathrm{Zr}_{\text {sap }}$ are based on the average $\mathrm{Zr}$ concentration in soil and saprolite of each depth profile, $\mathrm{Zr}_{\mathrm{r} \text { rock }}$ is based on the average of all bedrock samples collected in one specific study area (see Table S3 based on Oeser et al., 2018). The chemical depletion fraction $\mathrm{CDF}_{\text {total }}$ is determined by the fraction of the total chemical weathering rate $\mathrm{W}_{\text {total }}$ (as the sum of $\mathrm{W}_{\text {soil }}$ and $\mathrm{W}_{\text {sap }}$ ) and the total denudation rate $\mathrm{D}_{\text {total }}$ (Tables $\mathrm{S} 4$ and $\mathrm{S} 5$ ). As all results presented below are based on the notation of Dixon et al. (2009), the total denudation rates include the contribution of weathering in the saprolite. We note that this is in contrast to the total denudation rates presented in Oeser et al. (2018) which do not account for weathering in the saprolite and are considered as minimum denudation rate estimates.

\subsection{Global data compilation, correlation, and model simulations}

175 SPRs from the Chilean study areas were compared to previously published SPRs derived from granitic (Table S6) and nongranitic (Table S7) soil-mantled hillslopes from around the world. For the globally distributed granitic sample locations, a range of topographic, climate, and vegetation parameters were compiled (for details see Supplemental text 1). These SPRs and parameters were analyzed with a linear correlation analysis (Table S8). The MAP, MAT, leaf area index LAI, and SPRs 
at sample locations in the global compilation were also compared to available model simulations (for details see Supplemental text 2). In addition, chemical weathering and physical erosion rates determined in granitic soil-mantled hillslopes around the world were compiled. Some climate and vegetation parameters were determined (Table S9) and analyzed for linear correlations with chemical weathering and physical erosion rates (Table S10).

\section{Results}

In this section, results for soil production, chemical weathering, and physical erosion rates are presented for the new and previously published cosmogenic nuclide concentrations from the Chilean study areas (Fig., 2; Tables S2, S4, and S5). Results are given for each study area starting in the arid North and progressing to the South. The total denudation rates (Dtotal) presented below are the composite of the total chemical weathering rate $\left(\mathrm{W}_{\text {total }}\right)$ and the physical erosion rate $\left(\mathrm{E}_{\text {soil }}\right)$ and based on calculated SPRs and the Zr concentrations in rock, saprolite, and soil (Table S3). Because the observations presented in our global compilation were previously published (see references in Tables S6 and S8), we do not present the compilation in this section but rather in section 5 (Discussion) where it is integrated and discussed in the context of our Chilean observations. In addition, correlations of SPRs as well as chemical weathering and physical erosion rates with parameters are also shown in section 5 .

\section{1 Pan de Azúcar}

The in situ-produced ${ }^{10} \mathrm{Be}$ concentrations in quartz range from $(2.58 \pm 0.08) \times 10^{5}$ atoms $/ \mathrm{g}_{(\mathrm{qtz})}$ to $(5.08 \pm 0.16) \times 10^{5}$ atoms $/ \mathrm{g}_{(\mathrm{qtz})}$

195 (Table S2). The South-facing slope of Pan de Azúcar has SPRs that increase from $7.7 \pm 0.5 \mathrm{t} /\left(\mathrm{km}^{2} \mathrm{x} \mathrm{yr}\right)$ in the top-slope position to $16.8( \pm 1.0) \mathrm{t} /\left(\mathrm{km}^{2} \mathrm{yr}\right)$ in the toe-slope (Fig. 2A; Table S2). The North-facing mid-slope position has a lower SPR than the South-facing mid-slope position. The average $\mathrm{Zr}$ concentration of bedrock in Pan de Azúcar is $206 \pm 8 \mathrm{ppm}$, whereas $\mathrm{Zr}$ concentrations in soil and saprolite are between $184 \pm 14$ and $272 \pm 75 \mathrm{ppm}$ (Table S3). The averaged $\mathrm{Zr}_{\text {soil }} / \mathrm{Zr}_{\text {rock }}$ ratio in Pan de Azúcar is $1.07 \pm 0.09$ (Table S4) indicating no enrichment of the immobile element $\mathrm{Zr}$ from rock to soil. Chemical

200 weathering rates are low $<1.7 \pm 0.8 \mathrm{t} /\left(\mathrm{km}^{2} \mathrm{yr}\right)$; Fig. 2B; Table S4) and with an average value of $0.3 \pm 0.3 \mathrm{t} /\left(\mathrm{km}^{2} \mathrm{yr}\right)$. The average total denudation rate of $11.0 \pm 0.24 \mathrm{t} /\left(\mathrm{km}^{2} \mathrm{yr}\right)$ is dominated by the physical erosion rate with an average value for the study location of $10.7 \pm 2.6 \mathrm{t} /\left(\mathrm{km}^{2} \mathrm{yr}\right)$. This results in an average $\mathrm{CDF}_{\text {total }}$ of $0.05 \pm 0.08$ (Table S5).

\section{2 Santa Gracia}

205 In Santa Gracia, ${ }^{10} \mathrm{Be}$ concentrations in quartz range from $(1.75 \pm 0.06) \times 10^{5}$ atoms $/ \mathrm{g}_{(\mathrm{qtz})}$ and $(4.19 \pm 0.23) \times 10^{5}$ atoms $/ \mathrm{g}_{(\mathrm{qtz})}$ (Table S2). In the South-facing slope of Santa Gracia, where six samples were collected from top- to toe-slope positions (Tables S1 and S2), SPRs generally increase downslope from $17.8 \pm 1.3$ to $28.0 \pm 1.7 \mathrm{t} /\left(\mathrm{km}^{2} \mathrm{yr}\right)$. The SPR in the North-facing 
mid-slope position is lower than the equivalent mid-slope position in the South-facing slope (Fig. 2A; Table S2). The $\mathrm{Zr}_{\text {soil }} / \mathrm{Zr}_{\text {rock }}$ ratios are around 2 but subject to a large uncertainty due to inhomogeneity in the $\mathrm{Zr}_{\text {rock }}$ concentration (Table S3). Nevertheless, the averaged ratio of $\mathrm{Zr}_{\text {soil }} / \mathrm{Zr}_{\text {rock }}$ is $2.10 \pm 0.08$ indicating enrichment of the immobile element $\mathrm{Zr}$ from rock to soil. An estimated $80 \%$ of the weathering is located in the saprolite (Table S4). Total chemical weathering rates range from $11.0 \pm 5.4 \mathrm{t} /\left(\mathrm{km}^{2} \mathrm{yr}\right)$ to $30.4 \pm 16.0 \mathrm{t} /\left(\mathrm{km}^{2} \mathrm{yr}\right.$ ) (Fig. $2 \mathrm{~B}$ ). Higher chemical weathering rates are calculated for weathering in saprolite than in soil (Fig. S2; Table S4). Total chemical weathering and physical erosion rates contribute equally to the total denudation rate (Table S5). This is reflected in the average $\mathrm{CDF}_{\text {total }}$ of $0.52 \pm 0.02$.

\section{3 La Campana}

In situ-produced ${ }^{10} \mathrm{Be}$ concentrations in La Campana range from $(0.22 \pm 0.01) \times 10^{5} \mathrm{atoms} / \mathrm{g}_{(\mathrm{qtz})}$ to $(1.61 \pm 0.06) \times 10^{5}$ atoms $/ \mathrm{g}_{(\mathrm{qtz})}$ (Table S2). In La Campana the SPRs in the South-facing slope increase from top- to toe-slope with values of $42.1 \pm 2.6$ to $290.5 \pm 24.0 \mathrm{t} /\left(\mathrm{km}^{2} \mathrm{yr}\right)$ ) (Table S2). The SPR in the North-facing mid-slope position is slightly higher than the rate in the equivalent South-facing position (Fig. 2A; Table S2). Zirconium concentrations from rock to soil increase in La Campana 220 (Table S3). The chemical weathering rates in La Campana range from $20.2 \pm 2.6 \mathrm{t} /\left(\mathrm{km}^{2} \mathrm{yr}\right)$ to $30.4 \pm 16.0 \mathrm{t} /\left(\mathrm{km}^{2} \mathrm{yr}\right)$. About $60 \%$ of the chemical weathering occurs in the saprolite. The average total chemical weathering rate in La Campana of 95.0 $\pm 44.7 \mathrm{t} /\left(\mathrm{km}^{2} \mathrm{yr}\right)$ is affected by a large standard error of the mean. This large error arises from the exceptionally high SPR of sample LCPED30 likely related to a high topographic slope of $35^{\circ}$. Excluding this sample results in a total chemical weathering rate of $56.6 \pm 32.2 \mathrm{t} /\left(\mathrm{km}^{2} \mathrm{yr}\right)$ and a total denudation rate of $98.8 \pm 28.1 \mathrm{t} /\left(\mathrm{km}^{2} \mathrm{yr}\right)$ (Table $\left.\mathrm{S} 4\right)$. The corrected average $\mathrm{CDF}_{\text {total }}$ is $0.50 \pm 0.10$ indicating that half of the total denudation is due to chemical weathering (Table S5).

\section{4 Nahuelbuta}

${ }^{10} \mathrm{Be}$ concentrations in quartz range from $(1.24 \pm 0.05) \times 10^{5}$ atoms $/ \mathrm{g}_{(\mathrm{qtz})}$ to $(3.83 \pm 0.13) \times 10^{5}$ atoms $/ \mathrm{g}_{(\mathrm{qtz})}$ (Table S2) The SPRs from the South-facing slope in Nahuelbuta are within error, but increase slightly downslope from $57.7 \pm 3.5$ to $68.6 \pm 4.2 \mathrm{t} /\left(\mathrm{km}^{2}\right.$ yr) (Table S2). The SPR in the mid-slope position of the North-facing slope is much lower than the rate from the mid-slope position in the South-facing slope (Fig. 2A; Table S2). The increase of zirconium from rock to soil is less pronounced in Nahuelbuta than in Santa Gracia or La Campana (Averaged $\mathrm{Zr}_{\text {soil }} / \mathrm{Z} \mathrm{r}_{\text {rock }}$ ratio of $1.39 \pm 0.12$; Tables S3 and S4). Chemical weathering rates indicate a wide range between $4.4 \pm 15.5 \mathrm{t} /\left(\mathrm{km}^{2}\right.$ yr to $31.3 \pm 5.1 \mathrm{t} /\left(\mathrm{km}^{2} \mathrm{yr}\right)$. However, sample NAPED20 is excluded from further average calculations and discussion due to the observed decrease in $\mathrm{Zr}$ concentration from bedrock into saprolite resulting in a negative value of $\mathrm{W}_{\text {sap }}$ (Table S5). Hence, physical erosion rates vary between $20.0 \pm 1.2 \mathrm{t} /\left(\mathrm{km}^{2} \mathrm{yr}\right)$ and $23555.1 \pm 3.5 \mathrm{t} /\left(\mathrm{km}^{2} \mathrm{yr}\right)$. The average $\mathrm{CDF}_{\text {total }}$ of $0.30 \pm 0.06$ indicates that physical erosion rate is higher than the chemical weathering rate (Tables $\mathrm{S} 4$ and $\mathrm{S} 5$ ). 
In summary, SPRs generally increase from Pan de Azúcar to La Campana and are lower again in Nahuelbuta (Fig. 2A). From North to South, the same trend is observed in the chemical weathering rates (Fig. 2B). A similar trend is observed in the physical erosion rates except that rates are comparable in La Campana and Nahuelbuta (Fig. 2C). The total denudation rate combining chemical weathering and physical erosion rates increases from Pan de Azucar to La Campana and decreases in Nahuelbuta to a slightly higher value than in Santa Gracia (Fig. 2D). The $\mathrm{CDF}_{\text {total }}$ values, the contribution of $\mathrm{W}_{\text {total }}$ to $\mathrm{D}_{\text {total }}$, are almost zero in Pan de Azúcar, about equal ( 0.5) in Santa Gracia as well as in La Campana, and reduced again in Nahuelbuta $\left(\sim 0.3\right.$; Table S5). Nevertheless, $\mathrm{W}_{\text {total }}$ and $\mathrm{D}_{\text {total }}$ of all samples from the four study areas correlate very well $\left(\mathrm{R}^{2}=\right.$ $0.96)$ with a slope of 0.50 (Fig. S3A).

\section{Discussion}

In the following sections, the SPRs, chemical weathering and physical erosion rates calculated for the Chilean study areas are discussed and compared to the global compilation. Whereas section 5.1 addresses SPRs, section 5.2 discusses findings and problems observed with chemical weathering and physical erosion rates.

\section{1 Soil production rates}

In this section SPRs from the Chilean Coastal Cordillera are compared to a global data compilation of SPRs from granitic soil-mantled hillslopes in the light of MAP of the sample locations. The global data compilation from granitic lithologies is investigated for correlations of SPRs with topography, climate, and vegetation (leaf area index, LAI) metrics. Lastly, the SPRs are compared to model predicted variations in SPRs for different climate and vegetation settings.

\subsubsection{Comparison of global SPR compilation based on MAP}

The SPRs in the Chilean Coastal Cordillera increase from North to South from Pan de Azúcar to La Campana and are slightly lower again in Nahuelbuta (Fig. 2A). Comparison of MAP to the Chilean and global compilation of SPRs from soil-mantled hillslopes on granitic lithologies highlights several commonalities (Fig. 3A, Table S6). The maximum in SPRs ( $\sim 900 \mathrm{t} /\left(\mathrm{km}^{2}\right.$ yr)) occurs at MAP values between $\sim 500$ to $600 \mathrm{~mm} / \mathrm{yr}$. After this maximum, SPRs generally decrease with increasing MAP with the exception of two SPRs from a mountain crest with zero slope that form a second maximum (red symbols, Fig. 3A, from the Jalisco Highlands; Riebe et al., 2004a). The maximum in SPRs is dominated by locations with high slopes $\left(>30^{\circ}\right.$; green symbols, Fig. 3A) from the tectonically active San Gabriel Mountains (Heimsath et al., 2012). The findings of high SPRs with steep slopes are consistent with previous work (e.g., Binnie et al., 2007). The second maximum (Jalisco Highlands) is the result of highest SPRs reported from hillslopes with little or no soil (e.g., see findings of Heimsath et al., 1997). However, due to the reported low slope at a mountain crest the two data points from the Jalisco Highlands (Riebe et al., 2004a) are excluded from further analysis. Furthermore, the highest SPRs from samples with slopes $>30^{\circ}$ (Fig. 3A) agree well with the maximum SPRs for bare rock predicted from the 'maximum SPR model' of Norton et al. (2014; black line Fig. 3A, see also 
https://doi.org/10.5194/esurf-2021-22

Preprint. Discussion started: 1 April 2021

(c) Author(s) 2021. CC BY 4.0 License.

Supplement S2 for summary of model equations). This model predicts a linear increase in SPRs with increasing MAP. A purely linear relationship between SPRs and MAP is not evident for either Chilean or the global data set observed for MAP > $\sim 600 \mathrm{~mm} / \mathrm{yr}$ or for locations with slopes $<30^{\circ}$ (Fig. 3A). We also note that a similar increase and then decrease in SPRs with increasing MAP is also observed for non-granitic soil-mantled hillslopes (Fig. 3B). However, the maximum in SPRs in these settings is not only higher than in granitic lithologies but also reached at a higher MAP $(\sim 3,000 \mathrm{~mm} / \mathrm{yr})$. This discrepancy between the trend in SPR with MAP for granitic vs. non-granitic catchments is perplexing, but is most easily explained by previous work (e.g., Heimsath and Whipple, 2019) that highlights the importance of lithology and rock strength variations when interpreting SPRs.

The previously described trend of an increase and then decrease in SPR with increasing MAP is in contrast with the increase of SPRs predicted from the maximum SPRs for bare rock predicted with the model of Norton et al. (2014). This observation suggests that additional processes other than MAP influence the relationship. The observed decrease in SPR at MAP >600 $\mathrm{mm} / \mathrm{yr}$ (Fig. 3A) could, for example, be attributed to other climate and vegetation (e.g., Langbein and Schumm, 1958; Amundson et al., 2015; Richardson et al., 2019; Mishra et al., 2019; Starke et al., 2020) effects on SPR and soil thickness. We note that the relationship in SPR and MAP identified here for Chile, and also present in the global compilation, are not a new result (e.g., Mishra et al., 2019), but have been obfuscated in previous studies by nature of the data being plotted in log-log (e.g., Fig. 3C) rather than linear plots (e.g., Fig. 3A and 3B and all other plots of this study). In the following, we investigate the non-linear effect of climate and vegetation on SPRs (for granitic soil-mantled hillslopes only) with respect to different location specific parameters (e.g., MAT, LAI, slope, soil thickness).

\subsubsection{Correlation of SPRs with topography climate, and vegetation parameters}

As expected from the previous section, the SPRs of granitic soil-mantled hillsopes and MAP are only weakly (inversely) correlated $(\mathrm{R}=-0.16 ; \mathrm{p}<0.05$; Table $\mathrm{S} 8$ ). The best, but still weak, linear correlation of SPRs is achieved with local slopes (DEM GTOPO30; R = 0.37; $<<0.05$; Table S8). Other parameters weekly correlating with SPRs are the mean altitude and MAT at the sample location. Remaining parameters investigated suggest an even weaker correlation with SPRs than the previously mentioned slopes, mean altitude and MAT correlations. In summary, based on the above linear correlation analysis, there is little evidence for any one parameter exerting a linear control on SPR. Given this, in the following the non-linear relationship between SPRs and three parameters (MAP, MAT, and LAI) are qualitatively investigated in more detail before we compare these relationships to different proposed models for SPR (Fig. 4). As previously mentioned, SPRs increase with increasing MAP and then decrease. However, hillslopes with slopes $>30^{\circ}$ clearly document the highest SPRs (e.g., green symbols, Fig. 4) and decrease with decreasing slope (Fig. S4). Therefore, we group SPRs into slope bins and apply polynomial fits to the different slope bins to qualitatively help guide the readers eye for the trend in the data.

We find that the maximum in the peak of the SPRs shifts to higher MAP values with decreasing slopes (Fig. 4A), but regardless of the slope the same general trend in the data is evident where by SPR initially increase, and then decrease towards higher MAP. The relationship between SPR and MAT is less clear (Fig. 4B) aside from that SPRs generally decrease with decreasing 
https://doi.org/10.5194/esurf-2021-22

Preprint. Discussion started: 1 April 2021

(c) Author(s) 2021. CC BY 4.0 License.

slopes. Furthermore, there is a shift from a peak in SPRs at $\sim 10^{\circ} \mathrm{C}$ for slopes of $>30^{\circ}$ (green line in Fig. 4B) to maximum values in SPRs occuring at low temperatures for slopes $<20^{\circ}$ (orange and red lines, Fig. 4B). In contrast, we find SPRs increase with increasing $\mathrm{LAI}$ to a maximum value of $\mathrm{LAI}=\sim 2.2 \mathrm{~m}^{2} / \mathrm{m}^{2}$ irrespective of slope (Fig. 4C). Furthermore, low SPRs can be found in landscapes with either thin soils and low MAP or thick soils and high MAP (Fig. S5). Whereas the former are landscapes with low LAI, the latter are governed by high LAI. For example, in landscapes subjected to a dry climate (e.g., Pan de Azúcar Chilean site), thin soils with little vegetation cause reduced SPR due to a combination of diminished abiotic and biotic weathering processes. Reduced SPRs are also observed in landscapes with a humid climate (e.g., Nahuelbuta Chilean site) with thick soils, and abundant vegetation. As SPR is a process of chemical weathering and physical erosion a more detailed discussion is presented concerning patterns in chemical weathering and physical erosion rates.

\subsubsection{Comparison of predicted climate and vegetation effects on SPRs}

Previous observations of SPRs, climate, and vegetation have motivated different approaches to identify the functional relationship between these parameters. These studies stem from the empirically derived relationship proposed by Heimsath et al. (1997). Here we highlight three previous approaches (e.g., Fig. 5 and S6) aimed at quantifying the effects of MAP, MAT, and in some cases LAI, on SPRs (see Supplemental Material S2 for equations used). An overview of the approaches considered are as follows. First, Norton et al. (2014) developed an empirical soil production function to determine maximum SPRs based on MAP, MAT, and variable depth of soil cover (Fig. 5A and B). Second, Pelletier and Rasmussen (2009) used the "effective energy and mass transfer" (EEMT) approach of Rasmussen and Tabor (2007) to calculate SPRs (Fig. S6). Biotic controls are included in EEMT through the influence of MAP and MAT on biota. Finally (third), Pelak et al. (2016) developed a production rate function assuming the abiotic production rate is constant, and the biotic effects are calculated based on present-day soil depth and vegetation biomass (Fig. 5C). The previous studies suggest markedly different functional relationships between MAP, MAT, vegetation, and SPRs, thereby highlighting uncertainty in our current knowledge.

General trends in the controls on SPRs are, however, visible from observations. Maximum SPRs (under a constant average MAT of $14^{\circ} \mathrm{C}$ ) rapidly increase with increasing MAP to high values (Fig. 5A, black bold line). The maximum SPRs of Norton et al. (2014) explain the observed highest rates but fail to capture the observed decrease in SPRs with increasing MAP ( at MAP $>\sim 600 \mathrm{~mm} / \mathrm{yr}$ ). Furthermore, the Norton et al. model predicts that if soil depths are thicker than predicted maximum SPRs decrease (Fig. 5A, black stippled lines). However, the previously described approach of Norton et al. (2014) does not account for increases in soil depth that are observed with increasing precipitation and vegetation cover (e.g., Rasmussen and Tabor, 2007; Pelak et al., 2016). To explore the combined effects of variable soil depth with MAP (and hence vegetation cover) on SPRs we modified the approach of Norton et al. (2014) (see Supplementary Material S2) to account for increasing soil depth with increasing MAP (Fig. 5A; blue curve). Using this modified approach, the SPRs reach a maximum around $1,100 \mathrm{~mm} / \mathrm{yr}$ MAP and then decrease with higher MAP. This modification to the approach of Norton et al., (2014) results in a predicted relationship more similar to global observations whereby SPRs initially increase, reach a maximum value, and then decrease as MAP increases. Although the blue curve in Fig. 5A does not provide a good fit to observations (in part because 
https://doi.org/10.5194/esurf-2021-22

Preprint. Discussion started: 1 April 2021

(c) Author(s) 2021. CC BY 4.0 License.

each sample location has a different MAT), we note that the general trend in the model predictions and data are more closely matched, thereby highlighting the potential importance of considering soil depth variations in this type of analysis. The relationship between MAT and SPR is less clear (Fig. 5B). Here, the predicted maximum SPRs using the approach of Norton et al., (2014) are shown (black lines, Fig. 5B) for different MAT, assuming no soil depth and variable MAP from 1000 to 10 $\mathrm{mm} / \mathrm{yr}$. Comparison between the predicted and observed SPR for different magnitudes of MAP shows a general disagreement between model predictions and observations using this approach.

The influences of temperature and precipitation on SPR are often conceptualized as the main contributors to abiotic weathering. However, variations in MAP and MAT are a controlling factor in vegetation type and amount, which potentially influence biotic weathering and SPRs through their demand for nutrients. Support for vegetation influencing SPRs comes from the work of Pelak et al. (2016) (Fig. 5C, see Supplementary Material S2 for equations). In their approach, SPRs are calculated as a function of biomass which we represent with increasing LAI for comparison to our observations. This approach predicts an initial increase in SPRs with increasing LAI. The LAI value at which the maximum in SPRs occurs depends on the ratio of the vegetation growth rate $(\mathrm{r}$ ) over the vegetation turnover time $(\mathrm{m})$ (black curves Fig. 5C, see also Supplementary Material). The predicted increase then decrease in SPR shown in figure $5 \mathrm{C}$ is similar to the globally observed increase then decrease in SPRs with LAI.

In summary, based on the previous considerations, we find that global variations in observed SPRs can be explained by a combination of increasing MAP, increasing soil depth, and increasing vegetation (Fig. 5). Our interpretation is based on diverse factors that influence vegetation cover and both the biotic and abiotic 'engines' contributing to soil production. In addition to MAP and soil depth, we find that SPRs vary with topographic slope (Fig. 4A and S4, see also Heimsath et al.; 1997) and MAT. We note that although high-slope settings produce the highest SPRs, the trends in MAP and vegetation causing an increase and then decrease in SPRs as MAP or LAI increase occurs for different slope areas observed (Fig. 4).

\section{1 Chemical weathering and physical erosion rates}

In this section chemical weathering and physical erosion rates, and CDFs for the Chilean Coastal Cordillera are discussed. In addition, CDFs of this study are compared to the chemical index of alteration available for the climate and vegetation gradient of the Chilean Coastal Cordillera (Fig. 6). The Chilean data set is then compared to a global data compilation of soil-mantled hillslopes on granitic lithologies.

\subsubsection{Chilean data and relationships between climate, vegetation, and weathering}

Chemical weathering and physical erosion rates as well as CDFs are subject to large uncertainties due to incorporation of $\mathrm{Zr}$ concentrations for calculation. $\mathrm{Zr}$ concentrations in bedrock, saprolite, and soil may be highly variable and affect the calculation of weathering rates. Furthermore, available bedrock outcrops for sampling at neighboring locations may not be representative of the material the soil and saprolite formed from, as observed in our Santa Gracia Chilean study area (e.g., Fig.

3659 and $10 \mathrm{~b}$ in Oeser et al., 2018). Whereas this complication does not influence the calculation of $\mathrm{W}_{\text {soil }}$ or $\mathrm{E}_{\text {soil }}$ (and hence SPR), 
https://doi.org/10.5194/esurf-2021-22

Preprint. Discussion started: 1 April 2021

(c) Author(s) 2021. CC BY 4.0 License.

$\mathrm{W}_{\text {sap }}$ and $\mathrm{D}_{\text {total }}$ may be affected by inaccuracies in the $\mathrm{Zr}$ concentration used. However, as the $\mathrm{Zr}$ concentration of the average bedrock is lower than the $\mathrm{Zr}$ concentrations in soil and saprolite (Table S3), calculated $\mathrm{W}_{\text {sap }}$ and hence $\mathrm{D}_{\text {total }}$ are still meaningful. In contrast, the calculated fraction of weathering in saprolite for sample NAPED20 in Nahuelbuta is negative. This is caused by the $\mathrm{Zr}$ concentration in the saprolite which is lower than the concentration in the bedrock. The concentrations of $\mathrm{Zr}$ and also $\mathrm{Ti}$ in the saprolite are not consistent with soil production from bedrock over saprolite to soil (Table S3). Difficulties may also arise from aeolian and pedogenic input as for instance in the arid Pan de Azúcar study area, where pedogenic gypsum in the soil is reported (Bernhard et al., 2018). However, this pedogenic input only marginally affects the calculation of SPRs and $\mathrm{D}_{\text {total. }}$ Even though the calculation of chemical weathering and physical erosion rates are affected by large uncertainties some meaningful insights may be gained. For example, average $\mathrm{CDF}_{\text {total }}$ values of $0.05 \pm 0.08$ to $0.52 \pm 0.02$ reported for the four study areas (Table S5) indicate that where chemical weathering happens it can contribute up to $50 \%$ to the total denudation rate. The low $\mathrm{CDF}_{\text {total }}$ value of Pan de Azúcar can be explained by the absence of chemical weathering agents (e.g., carbonic acid produced from plant litter) and high $\mathrm{pH}$. However, the $\mathrm{CDF}_{\text {total }}$ value of $0.30 \pm 0.06$ reported from Nahuelbuta and the lower $\mathrm{W}_{\text {total }}$ in Nahuelbuta than La Campana to the orth requires further consideration.

The low $\mathrm{CDF}_{\text {total }}$ in Nahuelbuta can neither be explained by the lack of a weathering agent nor the influence of temperature on chemical weathering and physical erosion. For example, the wetter climate in Nahuelbuta than La Campana or Santa Gracia would suggest a high $\mathrm{W}_{\text {total }}$ in Nahuelbuta. This is shown by calculation of the silica fluxes in the four study areas based on equation 1 and values in Fig. 7 from Dixon et al. (2009). The calculated silica fluxes in Pan de Azúcar, Santa Gracia, La Campana, and Nahuelbuta are 14, 136, 316, and $746 \mathrm{~mol} /(\mathrm{ha} \mathrm{yr})$, respectively. These calculations indicate that the silica flux under the climate conditions in Nahuelbuta should be double the fluxes calculated for La Campana. This is clearly not reflected in the $\mathrm{W}_{\text {total }}$ values reported in this study. High weathering rates in Nahuelbuta are also expected due to the reported CIA for soils of 75 in Nahuelbuta which are higher than CIA in soils of the other study areas (Oeser et al., 2018).

Two explanations for the low values of $\mathrm{W}_{\text {total }}$ in Nahuelbuta could be based on the assumptions made for the calculations. First, in Nahuelbuta, low bulk densities in regolith $\left((0.8 \pm 0.1) \mathrm{g} / \mathrm{cm}^{3}\right)$ and high clay contents $(>25 \%)$ are observed (Bernhard et al., 2018). These regolith properties could indicate volcanic input. The volcanic input, in turn, could diminish the $\mathrm{Zr}$ concentration in soil and result in an underestimate of $\mathrm{W}_{\text {soil }}$. However, the chemical composition of the regolith and the pedogenic oxide content reveal no major volcanic influence in Nahuelbuta (Oeser et al., 2018).

A second explanation for the low values of $\mathrm{W}_{\text {total }}$ in Nahuelbuta could be a mobile behavior of the immobile elements (e.g., Yoo et al., 2007). Intense weathering of primary minerals should result in high $\mathrm{Zr}$ enrichment in soil unless $\mathrm{Zr}$ is mobile. The observation that the clay fraction in granitic regoliths is depleted in $\mathrm{Zr}$ (Taboada et al., 2006) supports the possibility that during weathering of primary to secondary minerals $\mathrm{Zr}$ is lost. The observation that the $\mathrm{Zr}$ concentration in regolith decreases with a decreasing $\mathrm{Si}$ to $\mathrm{Al}$ ratio in combination with the observation that secondary minerals have lower ratios of Si to $\mathrm{Al}$ than primary minerals (Yoo et al., 2007), further supports the possibility of $\mathrm{Zr}$ loss during weathering. Due to this possible $\mathrm{Zr}$ loss in regolith, the calculated $\mathrm{W}_{\text {soil }}$ is a minimum value leading to an underestimate of $\mathrm{W}_{\text {total }}$ and an overestimate of $\mathrm{E}_{\text {soil. }}$. Unfortunately, based on the available information, it is not clear if insulation by thick soils (Burke et al., 2007) and/or Zr loss 
https://doi.org/10.5194/esurf-2021-22

Preprint. Discussion started: 1 April 2021

(c) Author(s) 2021. CC BY 4.0 License.

by intense chemical weathering (Yoo et al., 2007) could cause low values of $\mathrm{W}_{\text {soil }}$ and a low $\mathrm{CDF}_{\text {total }}$ in Nahuelbuta. Recalculation of chemical weathering and physical erosion rates based on the assumption of an expected $\mathrm{CDF}_{\text {total }}$ of 0.5 in Nahuelbuta does not lead to higher $\mathrm{W}_{\text {total }}$ in Nahuelbuta than La Campana. After recalculation, the approximated averaged $\mathrm{W}_{\text {total }}$ is $\sim 30 \mathrm{t} /\left(\mathrm{km}^{2} \mathrm{yr}\right)$ instead of $19.6 \pm 7.8 \mathrm{t} /\left(\mathrm{km}^{2} \mathrm{yr}\right)$. As with recalculation $\mathrm{W}_{\text {sap }}$ does not change but $\mathrm{W}_{\text {soil }}$ increases (from $9.10 \pm 8.23 \mathrm{t} /\left(\mathrm{km}^{2} \mathrm{yr}\right.$ ) to $\sim 19 /\left(\mathrm{km}^{2} \mathrm{yr}\right)$ ) and $\mathrm{E}_{\text {soil }}$ decreases (from $39.4 \pm 10.3 \mathrm{t} /\left(\mathrm{km}^{2} \mathrm{yr}\right.$ ) to $\sim 30 \mathrm{t} /\left(\mathrm{km}^{2} \mathrm{yr}\right)$ ). Whereas $\mathrm{W}_{\text {total }}$ after correction is still higher in La Campana than in Nahuelbuta, $\mathrm{W}_{\text {soil }}$ is comparable. The recalculated $\mathrm{E}_{\text {soil }}$ of Nahuelbuta is still lower than the rate in La Campana. This decrease in physical erosion rate is attributed to stabilizing effects of plants. Total denudation rates $\mathrm{D}_{\text {total }}$, which did not change due to the recalculation, increases from Pan de Azúcar to La Campana and is lower again in Nahuelbuta.

A third explanation for lower weathering rates in Nahuelbuta than La Campana could also be the effect of microbial activity

410 (e.g., Buss et al., 2005; Eilers et al., 2012). Microbial abundance is precipitation, temperature and also pH sensitive (e.g., Fierer and Jackson, 2006; Bahram et al., 2018; Tan et al., 2020). For instance, microbial abundance increases and decreases in a tropical elevation-climate gradient where MAP increase and MAT decrease with increasing elevation (Peay et al., 2017). A comparable increase in MAP and decrease in MAT is observed in the Chilean Coastal Cordillera which is not only causing decreasing $\mathrm{pH}$ values from North to South but also lower bacterial abundance in Nahuelbuta than La Campana (Bernhard et al., 2018; Oeser et al., 2018). In order to investigate if the above made observations are unique in our study area, we proceed to compare data form this study with a global data compilation from granitic soil-mantled hillslopes.

\subsubsection{Comparison to global data compilation}

Similar to the Chilean Coastal Cordillera, the global data compilation also shows an increase and then decrease in the chemical weathering, physical erosion, and total denudation rates with increasing MAP (Fig. 6). In general, values of the CDF are around 0.4 to 0.6 in the global data compilation (Fig. 6 and S3B) and a strong coupling between rates of denudation and chemical weathering is observed (e.g., Riebe et al., 2001; Dixon et al., 2009; Granger and Riebe, 2014). However, values below and above 0.4 to 0.6 are also observed (Fig. 6). CDF values above 0.6 indicating extreme weathering rates are rare. CDF values corrected for the chemical erosion factor after Riebe and Granger (2013) from Puerto Rico and McNabb Track in New Zealand are higher than 0.6 (Table S9). More often, CDF values are lower than 0.4 and may even be close to zero indicating that chemical weathering is absent or reduced (e.g., Riebe et al., 2004a; Norton and von Blanckenburg, 2010; Ferrier et al., 2012). CDF values below 0.4 are reported from dry and hot places with low vegetation where water as a weathering agent is rare (e.g., Pan de Azúcar, this study). Other settings with low CDF values were previously encountered in cold regions with frost cracking and/or snow (e.g., Idaho Batholith, Ferrier et al., 2012; Switzerland, Norton and von Blanckenburg, 2010). Chemical weathering in cold regions might be low due to low temperatures which in turn enable frost cracking and snow increasing physical erosion rates and diminishing CDFs (Table S9). However, not only climate and vegetation influence values of CDFs but also topography. For example, low CDFs are reported from Point Reyes in California by Burke et al. (2007). This study area is underlain by a granodioritic lithology and located in a mediterranean climate with $800 \mathrm{~mm} / \mathrm{yr}$ of precipitation 
https://doi.org/10.5194/esurf-2021-22

Preprint. Discussion started: 1 April 2021

(c) Author(s) 2021. CC BY 4.0 License.

(Heimsath et al., 2005). The vegetation cover is grassland, shrubs, and trees, which host pocket gophers. CIA values of 59 for bedrock and 63 to 91 for soils (average 81) are reported. CDF values range from 0.06 to 0.75 with an average of 0.26. Average CDF values of thin soils $(<60 \mathrm{~cm})$ in divergent slope positions are 0.51 , whereas thick soils $(>60 \mathrm{~cm})$ in a divergent position and soils in convergent positions indicate an average value of 0.13 . Burke et al. (2007) concluded that thick soils act as a buffer against intense chemical weathering and inhibit high chemical weathering rates.

In summary, the decrease of CDFs with increasing MAP could be explained by reduced chemical weathering of saprolite due to buffering by thick soils (e.g., Burke et al., 2007). The protective nature of thick soils may distance vegetation from "fresh" nutrients in bedrock thereby leading to nutrient recycling (e.g., Oeser and von Blanckenburg, 2020; Koester et al., 2020) rather than acquisition from unweathered bedrock. This finding is consistent with previous work that has identified a decrease in chemical weathering rates with increased soil thickness as well as a 'speed limit' to chemical weathering rates (e.g., Dixon and von Blanckenburg, 2012). In essence, setting with dense vegetation could be functioning as a 'biotic break' on soil production and weathering.

\section{Conclusion}

Soil production, chemical weathering, and physical erosion rates change under the climate and vegetation gradients in the Chilean Coastal Cordillera. Whereas vegetation cover and mean annual precipitation increase from North to South, mean annual temperature decreases. SPRs increase from Pan de Azúcar to La Campana and decrease slightly in Nahuelbuta. Chemical weathering rates increase from zero in the North to the highest value of $211 \mathrm{t} /\left(\mathrm{km}^{2} \mathrm{yr}\right)$ in La Campana. Chemical weathering rates in Santa Gracia and Nahuelbuta are comparable $\left(\sim 20 \mathrm{t} /\left(\mathrm{km}^{2} \mathrm{yr}\right)\right.$. Hence, chemical weathering rates do not increase from North to South. Physical erosion rates are low in Pan de Azúcar ( $\left.\sim 10 \mathrm{t} /\left(\mathrm{km}^{2} \mathrm{yr}\right)\right)$, increase towards the South and are comparable in La Campana and Nahuelbuta $\left(\sim 40 \mathrm{t} /\left(\mathrm{km}^{2} \mathrm{yr}\right)\right)$. Combined total chemical weathering and physical erosion rates indicate that denudation rates are lowest in Pan de Azúcar and highest in La Campana. The contribution of chemical weathering to the total denudation rate is negligible in the North, and increases to $\sim 50 \%$ towards the South, and is lower again in Nahuelbuta.

The observations made in this setting and the comparison to global data lead to the following conclusions for the presented hypotheses:

1) Calculated soil production as well as chemical weathering rates do not increase with increasing mean annual precipitation. The decrease in SPRs at higher precipitation and vegetation is likely due to two factors. First, a 'speed limit' in weathering has been proposed to occur due to diverse abiotic and biotic processes occurring near the weathering front (e.g., Dixon and von Blanckenburg, 2012). Second, an additional biotic influence on SPRs may exist due to settings with higher vegetation/LAI having thicker and more nutrient depleted soils causing vegetation to switch to a nutrient recycling mode of near surface material (e.g., Jobbágy and Jackson, 2001) rather than harvesting fresh nutrients from deeply buried bedrock that would facilitate continued soil production. Thus, vegetation cover could be providing the 'biotic break' responsible for this 
https://doi.org/10.5194/esurf-2021-22

Preprint. Discussion started: 1 April 2021

(c) Author(s) 2021. CC BY 4.0 License.

465 speed limit. The observed decrease in chemical weathering rates is also at odds with an increasing chemical index of alteration which indicates an increase in the weathering trend from North to South. One explanation for the calculated low chemical weathering rate in the southernmost study area is the mobile behavior of generally immobile elements under high precipitation rates. Another explanation could be the protective nature of thick and clay-rich soils to intense weathering in the saprolite. Finally, latitudinal variations in microbial abundance due to climate and soil $\mathrm{pH}$ variations may influence biotically driven chemical weathering rates.

2) Calculated physical erosion rates stabilize from North to South with increasing precipitation. This stabilization may be caused by increasing vegetation cover protecting the soil from physical erosion.

3) The contribution of chemical weathering to total denudation rates increases and then decreases from North to South. In the northernmost study area, the low contribution in chemical weathering is due to the lack of a weathering agent. In

475 contrast, in the southernmost study area, which is affected by abundant solutes and rich in organic acids, thick soils and/or clay minerals may protect saprolite from intensive chemical weathering.

To conclude, soil production, chemical weathering, and physical erosion rates change with increasing MAP and LAI nonlinearly. Whereas increasing MAP has the potential to increase chemical weathering and physical erosion rates, vegetation decreases physical erosion rates and to a certain extent also chemical weathering rates.

\section{Author contribution}

Both authors (MS, TAE) contributed equally to the planning, execution, and manuscript preparation.

\section{Competing interest}

The authors declare that they have no conflict of interest.

\section{Acknowledgement}

485 We would like to thank the Chilean National Forestry Corporation (CONAF) for providing access to the sample locations and on-site support of our research.

\section{Financial support}

This work was funded by the German Science Foundation (DFG) priority research program SPP-1803 "EarthShape: Earth Surface Shaping by Biota" (grant SCHA 1690/3-1 to MS and EH329/14-2 to TAE). 
https://doi.org/10.5194/esurf-2021-22

Preprint. Discussion started: 1 April 2021

(c) Author(s) 2021. CC BY 4.0 License.

\section{References}

Amundson, R., Heimsath, A., Owen, J., Yoo, K. and Dietrich, W. E.: Hillslope soils and vegetation, Geomorphology, 234, 122-132, doi:10.1016/j.geomorph.2014.12.031, 2015.

Bahram, M., Hildebrand, F., Forslund, S.K., Anderson, J.S., Soudzilovskaia, N.A., Bodegom, P.M., Bengtsson-Palme, J., Anslan, S., Coelho, L.P., Harend, H., Huerta-Cepas, J., Medema, M.H., Maltz, M.R., Mundra, S., Olsson, P.A., Pent, M.,

495 Põlme, S., Sunagawa, S., Ryberg, M., Tedersoo, L. and Bork, P.: Structure and function of the global topsoil microbiome, Nature, 560, 233-237, doi.org/10.1038/s41586-018-0386-6, 2018.

Bernhard, N., Moskwa, L.-M., Schmidt, K., Oeser, R. A., Aburto, F., Bader, M. Y., Baumann, K., von Blanckenburg, F., Boy, J., van den Brink, L., Brucker, E., Büdel, B., Canessa, R., Dippold, M. A., Ehlers, T. A., Fuentes, J. P., Godoy, R., Jung, P., Karsten, U., Köster, M., Kuzyakov, Y., Leinweber, P., Neidhardt, H., Matus, F., Mueller, C. W., Oelmann, Y., Oses, R., Osses, 500 P., Paulino, L., Samolov, E., Schaller, M., Schmid, M., Spielvogel, S., Spohn, M., Stock, S., Stroncik, N., Tielbörger, K., Übernickel, K., Scholten, T., Seguel, O., Wagner, D. and Kühn, P.: Pedogenic and microbial interrelations to regional climate and local topography: New insights from a climate gradient (arid to humid) along the Coastal Cordillera of Chile, CATENA, 170, 335-355, doi:10.1016/j.catena.2018.06.018, 2018.

Binnie, S.A., Phillips, W.M., Summerfield, M.A., Fifield, L.K.: Tectonic uplift, threshold hillslopes, and denudation rates in a 505 developing mountain range, Geology, 35, 743-746, doi: 10.1130/G23641 A.1, 2007.

Borchers, B., Marrero, S., Balco, G., Caffee, M., Goehring, B., Lifton, N., Nishiizumi, K., Phillips, F., Schaefer, J. and Stone, J.: Geological calibration of spallation production rates in the CRONUS-Earth project, Quaternary Geochronology, 31, 188198, doi:10.1016/j.quageo.2015.01.009, 2016.

Braucher, R., Merchel, S., Borgomano, J. and Bourlès, D. L.: Production of cosmogenic radionuclides at great depth: A multi 510 element approach, Earth and Planetary Science Letters, 309(1-2), 1-9, doi:10.1016/j.eps1.2011.06.036, 2011.

Burke, B.C., Heimsath, A.M. and White, A.F.: Coupling chemical weathering with soil production across soil-mantled landscapes, Earth Surf. Process. Landforms, 32(6), 853-873, doi:10.1002/esp.1443, 2007.

Buss, H.L., Bruns, M.A., Schultz, M.J., Moore, J., Mathur, C.F. and Brantley, S.L.: The coupling of biological iron cycling and mineral weathering during saprolite formation, Luquillo Mountains, Puerto Rico, Geobiology, 3, 247-260, 515 doi.org/10.1111/j.1472-4669.2006.00058.x, 2005.

Dixon, J.L., Heimsath, A.M. and Amundson, R.: The critical role of climate and saprolite weathering in landscape evolution, Earth Surf. Process. Landforms, 34(11), 1507-1521, doi:10.1002/esp.1836, 2009.

Dixon, J.L. and von Blanckenburg, F.: Soils as pacemakers and limiters of global silicate weathering, Comptes Rendus Geoscience, 344(11-12), 597-609, doi:10.1016/j.crte.2012.10.012, 2012.

520 Eilers, K.C., Debenport, S., Anderson, S. and Fierer N.: Digging deeper to find unique microbial communities: The strong effect of depth on the structure of bacterial land archaeal communities in soil, Soil Biology and Biochemistry, 50, 58-65, doi:10.1016/j.soilbio.2012.03.011, 2012. 
https://doi.org/10.5194/esurf-2021-22

Preprint. Discussion started: 1 April 2021

(c) Author(s) 2021. CC BY 4.0 License.

Ferrier, K.L., Kirchner, J.W. and Finkel, R.C.: Weak influences of climate and mineral supply rates on chemical erosion rates: Measurements along two altitudinal transects in the Idaho Batholith: CLIMATE AND CHEMICAL EROSION RATES, J. Geophys. Res., 117(F2), n/a-n/a, doi:10.1029/2011JF002231, 2012.

Fierer, N. and Jackson, R.B.: The diversity and biogeography of soil bacterial communities, PNAS, 103 (3), 626-631, doi:10.1073/pnas.0507535103, 2006.

Granger, D.E. and Riebe, C.S.: Cosmogenic Nuclides in Weathering and Erosion, in Treatise on Geochemistry, pp. 401-436, Elsevier., 2014.

Heimsath, A.M. and Whipple, K.X.: Strength matters: Resisting erosion across upland landscapes, Earth Surf. Process. Landforms, 44(9), 1748-1754, doi:10.1002/esp.4609, 2019.

Heimsath, A.M., Dietrich, W.E., Nishiizumi, K. and Finkel, R.C.: The soil production function and landscape equilibrium, Nature, 388(6640), 358-361, doi:10.1038/41056, 1997.

Heimsath, A.M., Furbish, D.J. and Dietrich, W.E.: The illusion of diffusion: Field evidence for depth-dependent sediment transport, Geol, 33(12), 949, doi:10.1130/G21868.1, 2005.

Heimsath, A.M., DiBiase, R.A. and Whipple, K.X.: Soil production limits and the transition to bedrock-dominated landscapes, Nature Geosci, 5(3), 210-214, doi:10.1038/ngeo1380, 2012.

IUSS Working Group WRB. World reference base for soil resources 2014, update 2015. Prepared by Schad P, van Huyssteen C, Micheli E. 192 pp. World Soil Resources Reports No. 106, FAO, Rome. 2015.

Jobbágy, E.G. and Jackson, R.B.: The distribution of soil nutrients with depth: global patterns and the imprint of plants, Biogeochemistry, 53, 51-77, 2001.

Karger, D.N., Conrad, O., Böhner, J., Kawohl, T., Kreft, H., Soria-Auza, R.W., Zimmermann, N.E., Linder, H.P. and Kessler, M.: Climatologies at high resolution for the earth's land surface areas, Scientific Data, 4, sdata2017122, doi:10.1038/sdata.2017.122, 2017.

545 Koester, M., Stock, S.C., Nájera, F., Abdallah, K., Gorbushina, A., Prietzel, J., Matus, F., Klysubun, W., Boy, J., Kuzyakov, Y., Dippold, M.A., Spielvogel, S.: From rock eating to vegetarian ecosystems - Disentangling processes of phosphorus acquisition across biomes, Geoderma, doi.org/10.1016/j.geoderma.2020.114827, 2020.

Langbein, W.B. and Schumm, S.A.: Yield of sediment in relation to mean annual precipitation, Transactions, American Geophysical Union, 39, 1076-1084, doi:10.1029/TR039i006p01076, 1958.

550 Larsen, I.J., Almond, P.C., Eger, A., Stone, J.O., Montgomery, D.R. and Malcolm, B.: Rapid Soil Production and Weathering in the Southern Alps, New Zealand, Science, 343(6171), 637-640, doi:10.1126/science.1244908, 2014.

Marrero, S.M., Phillips, F.M., Borchers, B., Lifton, N., Aumer, R. and Balco, G.: Cosmogenic nuclide systematics and the CRONUScalc program, Quaternary Geochronology, 31, 160-187, doi:10.1016/j.quageo.2015.09.005, 2016.

Mishra, A.K., Placzek, C. and Jones, R.: Coupled influence of precipitation and vegetation on millennial-scale erosion rates derived from 10Be, edited by A. Zerboni, PLoS ONE, 14(1), e0211325, doi:10.1371/journal.pone.0211325, 2019. 
https://doi.org/10.5194/esurf-2021-22

Preprint. Discussion started: 1 April 2021

(c) Author(s) 2021. CC BY 4.0 License.

Mutz, S.G., Ehlers, T.A., Werner, M., Lohmann, G., Stepanek, C. and Li, J.: Estimates of late Cenozoic climate change relevant to Earth surface processes in tectonically active orogens, Earth Surface Dynamics, 6, 271-301, doi:10.5194/esurf-6-271-2018, 2018.

Mutz, S.G., Ehlers, T.A.: Detection and explation of spatiotemporal patterns in Late Cenozoic paleoclimate change relevant to Earth surface proceses, Earth Surface Dynamics, 7, 663-679, doi.org/10.5194/esurf-7-663-2019, 2019.

Nesbitt, W. and Young, G.M.: Early Proterozoic climates and plate motions inferred from major element chemistry of lutites, Nature, 299, 715-717, 1982.

Norton, K.P. and von Blanckenburg, F.: Silicate weathering of soil-mantled slopes in an active Alpine landscape, Geochimica et Cosmochimica Acta, 74(18), 5243-5258, doi:10.1016/j.gca.2010.06.019, 2010.

565 Norton, K.P., Molnar, P. and Schlunegger, F.: The role of climate-driven chemical weathering on soil production, Geomorphology, 204, 510-517, doi:10.1016/j.geomorph.2013.08.030, 2014.

Oeser, R.A., Stroncik, N., Moskwa, L.-M., Bernhard, N., Schaller, M., Canessa, R., van den Brink, L., Köster, M., Brucker, E., Stock, S., Fuentes, J.P., Godoy, R., Matus, F.J., Oses Pedraza, R., Osses McIntyre, P., Paulino, L., Seguel, O., Bader, M. Y., Boy, J., Dippold, M.A., Ehlers, T.A., Kühn, P., Kuzyakov, Y., Leinweber, P., Scholten, T., Spielvogel, S., Spohn, M., Übernickel, K., Tielbörger, K., Wagner, D. and von Blanckenburg, F.: Chemistry and microbiology of the Critical Zone along a steep climate and vegetation gradient in the Chilean Coastal Cordillera, CATENA, 170, 183-203, doi:10.1016/j.catena.2018.06.002, 2018.

Oeser, R.A. von Blanckenburg F.: Do degree and rate of silicate weathering depend on plant productivity? Biogeosciences. https://doi.org/10.5194/bg-17-4883-2020, 2020.

575 Peay, K.G., von Sperber, C., Candarelli, E., Toju, H., Francis, C.A., Chadwick, O.A. and Vitousek, P.M., Convergence and contrast in the community structure of Bacteria, Fungi and Archaea along a tropical elevation-climate gradient, FENS Microbiology Ecology, 93, doi: 10.1093/gemsec/fix0045, 2017/

Pelak, N.F., Parolari, A.J. and Porporato, A.: Bistable plant-soil dynamics and biogenic controls on the soil production function: BISTABLE PLANT-SOIL DYNAMICS, Earth Surf. Process. Landforms, 41(8), 1011-1017, doi:10.1002/esp.3878, 2016.

Pelletier, J.D. and Rasmussen, C.: Quantifying the climatic and tectonic controls on hillslope steepness and erosion rate, Lithosphere, 1(2), 73-80, doi:10.1130/L3.1, 2009.

Perron, J.T.: Climate and the pace of erosional landscape evolution, Annual Review of Earth and Planetary Sciences, 45, 461491, doi.org/10.1146/annurev- earth- 060614- 105405, 2017

585 Plug, L.J., Gosse, J.C., McIntosh, J.J. and Bigley, R.: Attenuation of cosmic ray flux in temperate forest, J. Geophys. Res., 112(F2), F02022, doi:10.1029/2006JF000668, 2007.

Rasmussen, C. and Tabor, N.J.: Applying a Quantitative Pedogenic Energy Model across a Range of Environmental Gradients, Soil Science Society of America Journal, 71(6), 1719, doi:10.2136/sssaj2007.0051, 2007. 
https://doi.org/10.5194/esurf-2021-22

Preprint. Discussion started: 1 April 2021

(c) Author(s) 2021. CC BY 4.0 License.

Richardson, P.W., Perron, J.T. and Schurr, N.D.: Influences of climate and life on hillslope sediment transport, Geology, 47(5),

423-426, doi:10.1130/G45305.1, 2019.

Riebe, C.S. and Granger, D.E.: Quantifying effects of deep and near-surface chemical erosion on cosmogenic nuclides in soils, saprolite, and sediment: EFFECTS OF CHEMICAL EROSION ON COSMOGENIC NUCLIDE BUILDUP, Earth Surf. Process. Landforms, 38(5), 523-533, doi:10.1002/esp.3339, 2013.

Riebe, C.S., Kirchner, J.W., Granger, D.E. and Finkel, R.C.: Minimal climatic control on erosion rates in the Sierra Nevada, 595 California, Geology, 29, 447-450, 2001.

Riebe, C.S., Kirchner, J.W. and Finkel, R.C.: Erosional and climatic effects on long-term chemical weathering rates in granitic landscapes spanning diverse climate regimes, Earth and Planetary Science Letters, 224(3-4), 547-562, doi:10.1016/j.epsl.2004.05.019, 2004a.

Riebe, C.S., Kirchner, J.W. and Finkel, R.C.: Sharp decrease in long-term chemical weathering rates along an altitudinal transect, Earth and Planetary Science Letters, 218(3-4), 421-434, doi:10.1016/S0012-821X(03)00673-3, 2004b.

Schaller, M., Ehlers, T.A., Lang, K.A.H., Schmid, M. and Fuentes-Espoz, J.P.: Addressing the contribution of climate and vegetation cover on hillslope denudation, Chilean Coastal Cordillera $\left(26^{\circ}-38^{\circ} \mathrm{S}\right)$, Earth and Planetary Science Letters, 489 , 111-122, doi:10.1016/j.eps1.2018.02.026, 2018.

Schmid, M., Ehlers, T.A., Werner, C., Hickler, T., and Fuentes-Espoz, J.-P. Effect of changing vegetation and precipitation on

denudation - Part 2: Predicted landscape response to transient climate and vegetation cover over millennial to million-year timescales, Earth Surface Dynamics, 6(4), 859-881, doi:10.5194/esurf-6-859-2018, 2018.

Starke, J., Ehlers, T.A. and Schaller, M.: Latitudinal effect of vegetation on erosion rates identified along western South America, Science, 367(6484), 1358-1361, https://doi.org/10.1126/science.aaz0840, 2020.

Taboada, T., Cortizas, A.M., García, C. and García-Rodeja, E.: Particle-size fractionation of titanium and zirconium during

610 weathering and pedogenesis of granitic rocks in NW Spain, Geoderma, 131(1-2), 218-236, doi:10.1016/j.geoderma.2005.03.025, 2006.

Tan, W., Wang, J., Bai, W., Qi, J. and Chen, W.: Soil bacterial diversity correlates with precipitation and soil pH in long-term maize cropping systems, Scientific Reports, 10, 6012, doi.org/10.1038/s41598-020-62919-7, 2020.

Werner, C., Schmid, M., Ehlers, T.A., Fuentes-Espoz, J.P., Steinkamp, J., Forrest, M., Liakka, J., Maldonado, A. and Hickler,

615 T.: Effect of changing vegetation and precipitation on denudation - Part 1: Predicted vegetation composition and cover over the last 21 thousand years along the Coastal Cordillera of Chile, Earth Surface Dynamics, 6, 829-858, doi:10.5194/esurf-6829-2018, 2018.

Yoo, K., Amundson, R., Heimsath, A.M., Dietrich, W.E. and Brimhall, G.H.: Integration of geochemical mass balance with sediment transport to calculate rates of soil chemical weathering and transport on hillslopes, Journal of Geophysical Research, 112(F2), doi:10.1029/2005JF000402, 2007. 
https://doi.org/10.5194/esurf-2021-22

Preprint. Discussion started: 1 April 2021

(c) Author(s) 2021. CC BY 4.0 License.

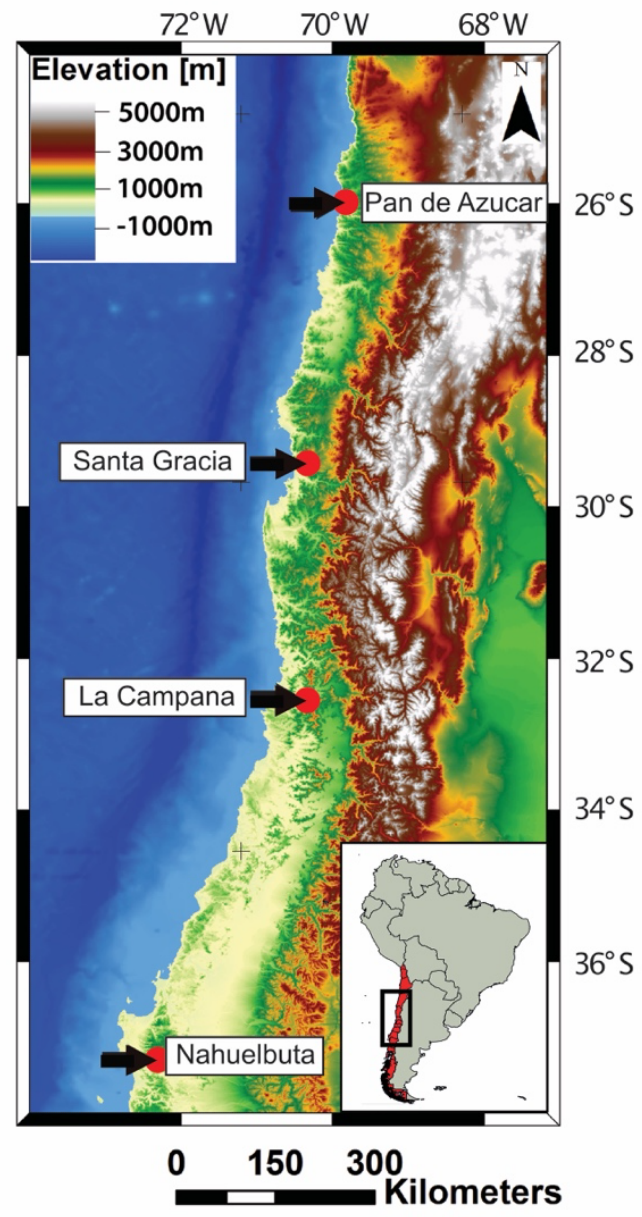

Figure 1: Digital elevation model (Data source: GTOPO30) with the locations of the four study areas (red circles) in the Chilean 625 Coastal Cordillera. The climate from North to South over $\sim \mathbf{1 2 0 0} \mathbf{~ k m}$ changes from arid to temperate humid. See Supplementary Material figure S1 photographs of each area and detailed satellite images of sample locations. 
https://doi.org/10.5194/esurf-2021-22

Preprint. Discussion started: 1 April 2021

(c) Author(s) 2021. CC BY 4.0 License.
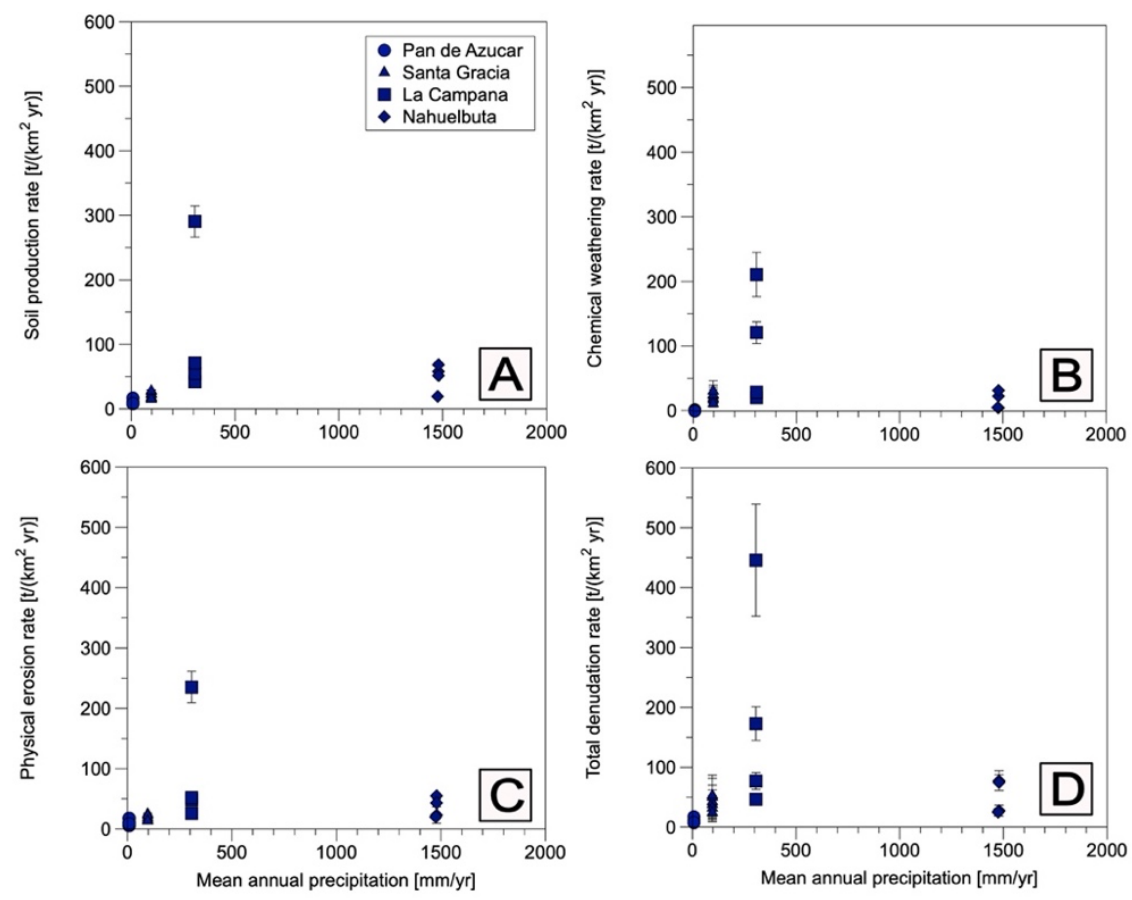

Figure 2: Cosmogenic nuclide-derived rates from pedon locations for four study areas (From North to South: Pan de Azúcar, Santa rates, B) chemical weathering rates, $C$ ) physical erosion rates, and D) total denudation rates versus mean annual precipitation 
https://doi.org/10.5194/esurf-2021-22

Preprint. Discussion started: 1 April 2021

(c) Author(s) 2021. CC BY 4.0 License.
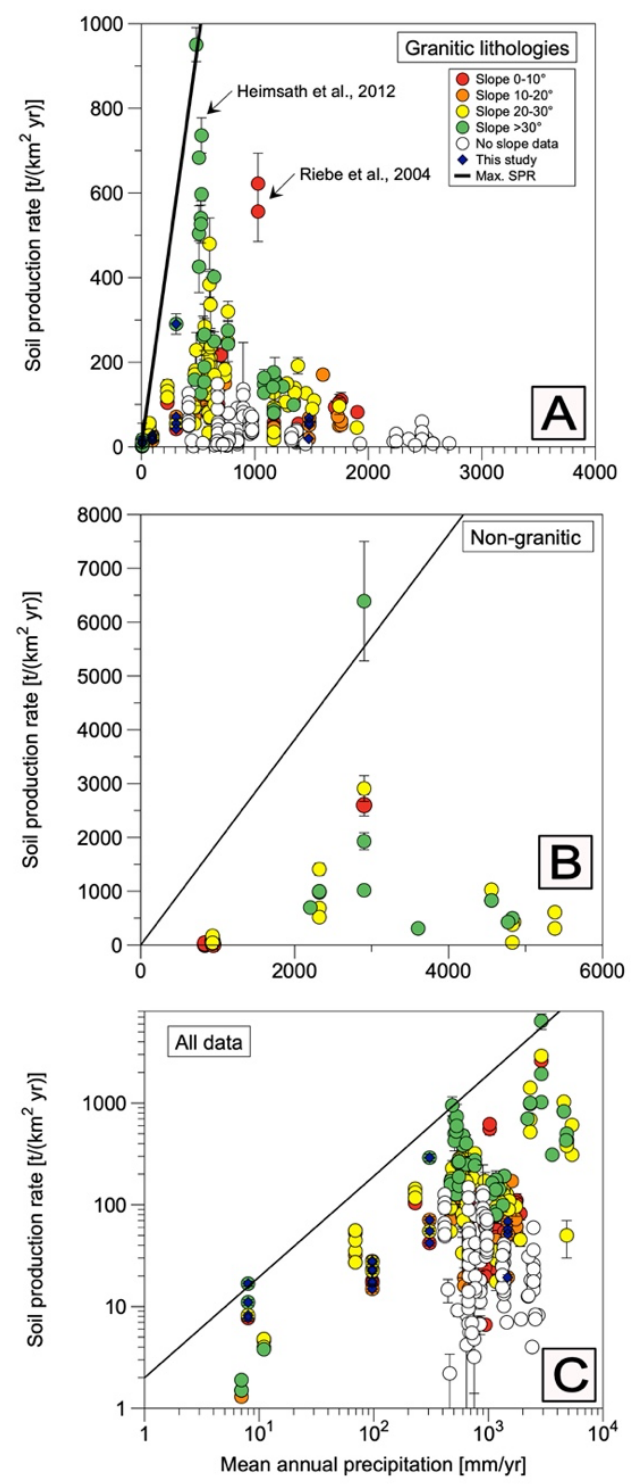

Figure 3: Soil production rates SPRs versus mean annual precipitation: A) SPRs from granitic lithologies such as samples from this study (blue diamonds). The data are in bins for different slopes. Note the linear axes as well as the black line for the maximum production rate after Norton et al. (2014) at a temperature of $14^{\circ} \mathrm{C}$. B) SPRs from some non-granitic lithologies. Note the increased linear axis in comparison to Fig. 3A. C) Compilation of all SPRs plotted with logarithmic axis. 
https://doi.org/10.5194/esurf-2021-22

Preprint. Discussion started: 1 April 2021

(c) Author(s) 2021. CC BY 4.0 License.
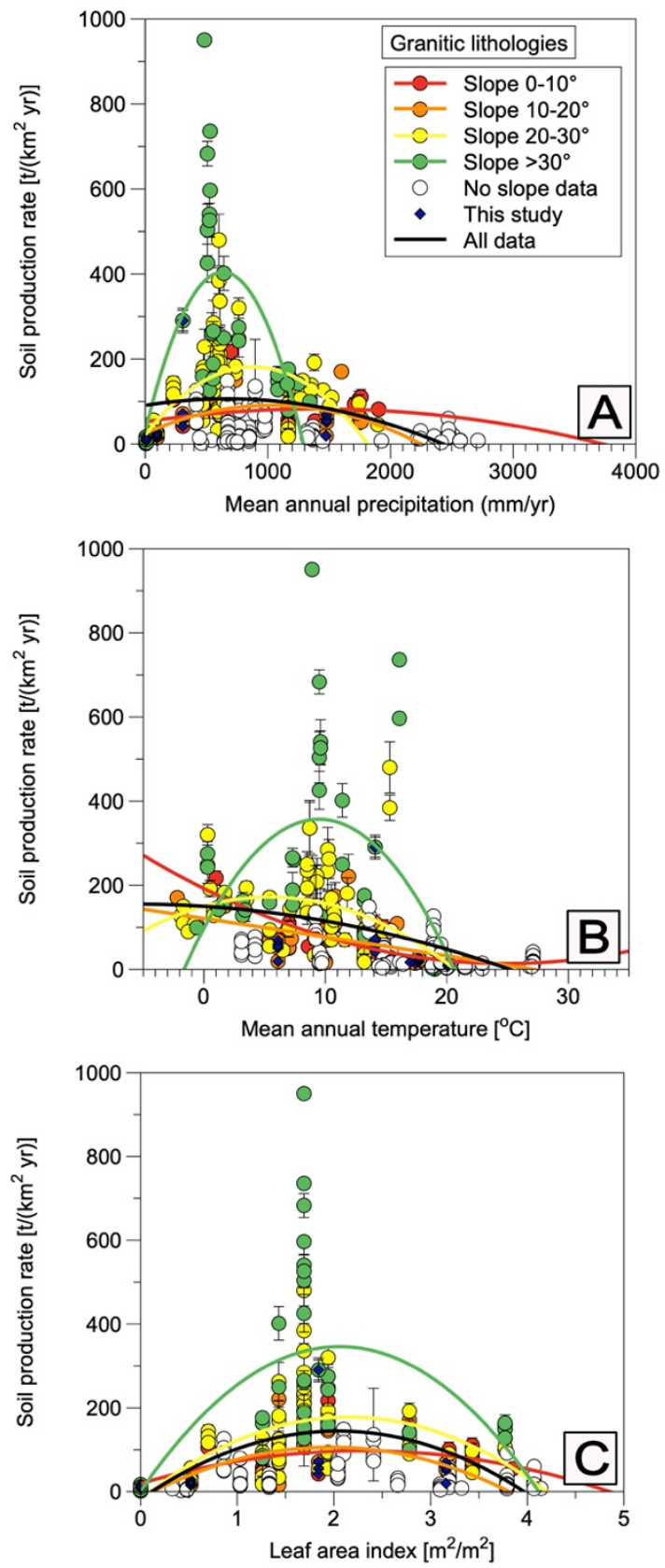

Figure 4: Soil production rates from this study (blue diamonds) and other studies in hillslopes with granitic lithologies versus: A)

640 Mean annual precipitation, B) Mean annual temperature, and C) Leaf area index. Data are separated in bin slopes and plotted with a two-polynomial fit. 
https://doi.org/10.5194/esurf-2021-22

Preprint. Discussion started: 1 April 2021

(c) Author(s) 2021. CC BY 4.0 License.
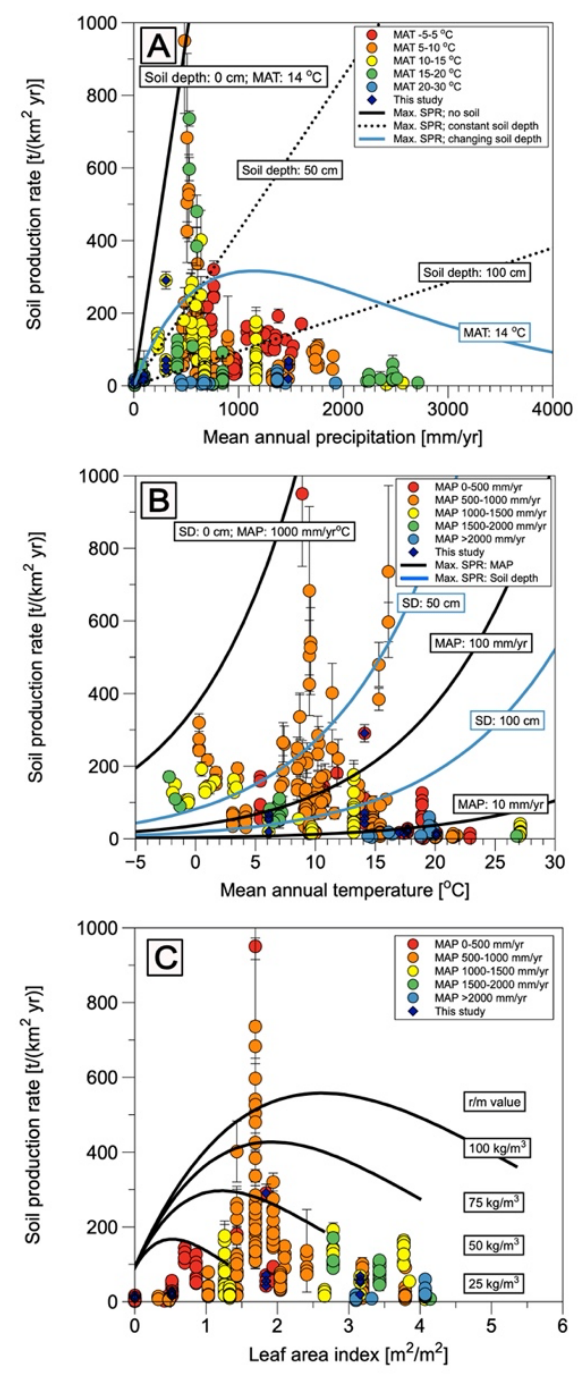

Figure 5: Soil production rates versus: A) Mean annual precipitation. The black bold and stippled lines indicate maximum SPRs for different soil depths (after Norton et al., 2014). Blue lines are maximum SPRs with increasing soil depth with increasing mean annual precipitation. Data are sorted in mean annual temperature bins. B) Mean annual temperature. Black lines are maximum SPRs for different mean annual precipitations and blue lines for different soil depths. Data sorted in mean annual precipitation bins. C) Leaf area index. Black lines are maximum SPRs for different biomasses (r/m value; after Pelak et al., 2016). Data sorted in mean annual precipitation bins. 
https://doi.org/10.5194/esurf-2021-22

Preprint. Discussion started: 1 April 2021

(c) Author(s) 2021. CC BY 4.0 License.
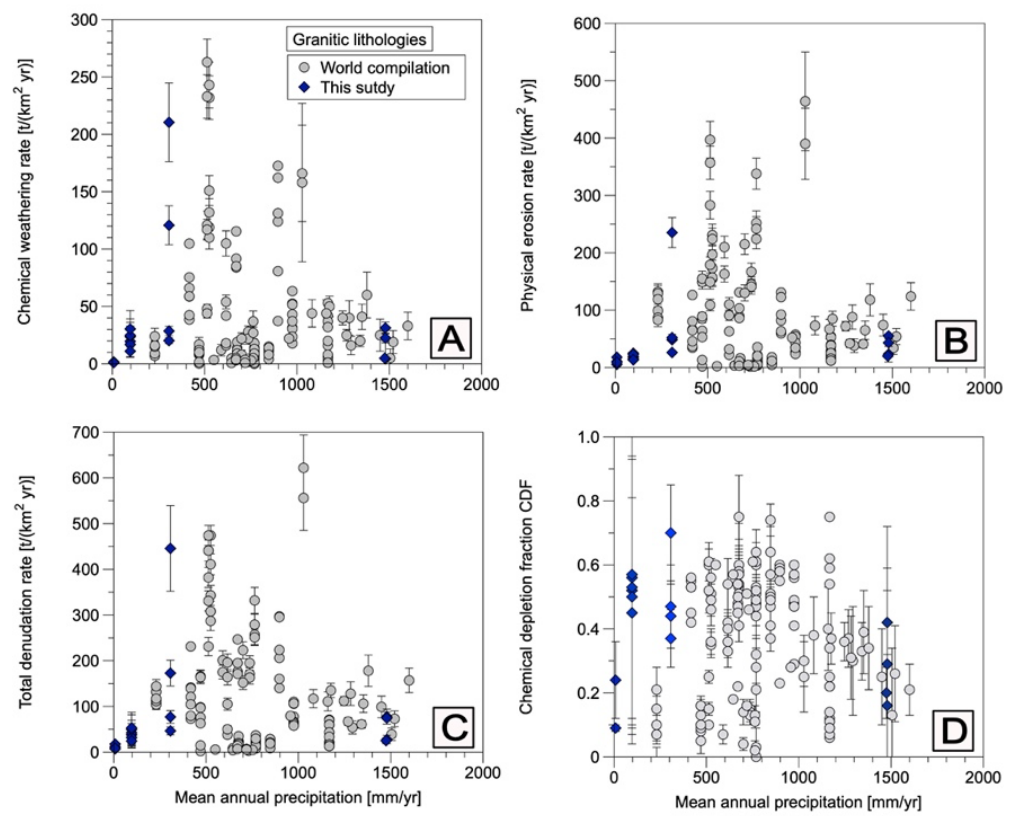

Figure 6: A) Chemical weathering rates, B) Physical erosion rates, C) Denudation rate, and D) Chemical depletion fraction CDF versus mean annual precipitation. Rates for the four study areas (blue diamonds) and comparison rates from different study areas situated in granitic soil-mantled hillslopes (gray dots). 